\title{
A INTERDISCIPLINARIDADE NO ENSINO DE BIOLOGIA POR MEIO DA EDUCAÇÃO AMBIENTAL
}

\author{
Paula Rebeca Alencar e Silva ${ }^{1}$ \\ Carla Ledi Korndörfer ${ }^{2}$ \\ Luciano da Silva Figueiredo ${ }^{3}$ \\ Elenice de Abreu Oliveira ${ }^{4}$
}

\begin{abstract}
Resumo: Diante da complexidade e diversidade das representações ambientais frente às práticas incipientes em Educação Ambiental (EA) que visam o reconhecimento de problemas ambientais e não o seu enfrentamento, este estudo objetivou analisar atividades interdisciplinares desenvolvidas sob enfoque crítico. Entrevistas semiestruturadas foram realizadas antes e depois da execução das atividades as quais foram desenvolvidas pautadas em temas ambientais locais. A partir delas foi constatado que os alunos possuíam uma visão naturalista de ambiente e relacionavam EA apenas com a natureza. A realização das atividades interdisciplinares viabilizou o entendimento da responsabilidade social e política da comunidade escolar e a visão ambiental se tornou globalizante.
\end{abstract}

Palavras-chave: Educação Ambiental Crítica; Ecopedagogia; Educomunicação; Cidadania.

Abstract: In view of the complexity and diversity of environmental representations in face of incipient practices in Environmental Education (EE) that aim to recognize environmental problems and not to face them, this study aimed to analyze interdisciplinary activities developed under a critical focus. Semi-structured interviews were carried out before and after the execution of the activities, which were developed based on local environmental themes. From them it was found that the students had a naturalistic view of the environment and related EE only to nature. The performance of interdisciplinary activities enabled the understanding of the social and political responsibility of the school community and the environmental vision became global.

Keywords: Critical Environmental Education; Ecopedagogy; Educommunication; Citizenship.

1 Universidade Estadual do Piauí. E-mail: paula.rebeca@outlook.com.

2 Universidade Estadual do Piauí. E-mail: calk1807@gmail.com.

3 Universidade Estadual do Piauí. E-mail: lucianosilva@pcs.uespi.br.

4 Universidade Estadual do Piauí. E-mail: eleniceabreu8@gmail.com 


\section{Introdução}

O acelerado crescimento populacional e o uso desenfreado dos recursos naturais para suprir as necessidades humanas tornaram o ambiente natural, outrora abundante, hoje, escasso, ameaçado e reduzido a áreas de preservação (BRASIL, 1997). No entanto, essa banalização tomou visibilidade social diante da gravidade e da diversidade dos problemas ambientais surgidos e a sociedade refletiu sua influência sobre esses problemas e questionou-se acerca da aquisição de novos modelos de consumo e produção de bens como solução para tais problemas (BRASIL, 2014).

Consoante com esta perspectiva, a Educação Ambiental (EA) configurou-se, a partir de sua inclusão na Constituição Federal de 1988, como um importante instrumento de questionamento e reflexão do paradigma econômico e social vigente. A sua importância para a formação de sujeitos históricos, críticos, cientes de sua relação com o ambiente foi firmada pela Lei ํo 9.795, de 27 de abril de 1999, regulamentada pelo Decreto o 4.281, de 25 de junho de 2002, que dispõe sobre a Política Nacional de Educação Ambiental (PNEA) e prevê em seu Artigo $2^{\circ}$ que "A Educação Ambiental é um componente essencial e permanente da educação nacional, devendo estar presente em todos os níveis e modalidades do processo educativo, em caráter formal e não formal" (BRASIL, 1999).

Instrumentos nacionais que regulamentam a educação brasileira como a Lei de Diretrizes e Bases da Educação Nacional (LDB) (BRASIL, 2010) salientam a importância da (re) formulação dos currículos, a fim de superar a fragmentação do saber na perspectiva de atender às demandas socioambientais contemporâneas utilizando abordagem educacional contextualizada (BIASIBETTI et al. 2015) e, mais atualmente, a Portaria № 1.570/2017 que regulamenta a Base Nacional Comum Curricular (BNCC) reafirma a importância de enriquecer os atuais modelos curriculares com temáticas socioambientais que afetam a vida humana, inserindo-os transversalmente (BRASIL, 2018).

O conhecimento compartilhado na esfera escolar deve estar estruturado de forma que permita ao aluno e à aluna a aquisição de domínio do conhecimento e a reafirmação da sua relação com o cotidiano, de forma que, aos poucos, ele e ela se tornem cidadão e cidadã do mundo (DELORS, 2010; BRASIL, 2014).

A EA vivenciada nas escolas demonstra um gradativo, porém incipiente, distanciamento das práticas conservadoras, as quais objetivam o simples reconhecimento dos problemas ambientais e não o seu enfrentamento, uma vez que apenas reconhecer não é suficiente (PINTO; GUIMARÃES, 2017). A corrente Crítica da EA, cujas concepções ideológicas orientaram o presente estudo, visa estabelecer reflexão crítico-transformadora sobre a responsabilidade da coletividade frente às problemáticas ambientais, levando em consideração os contextos histórico, cultural e social determinantes nas relações com o meio (CAVALCANTE, 2005).

Revbea, São Paulo, V. 16, № 4: 340-358, 2021.

revista brasileira educação ambiental 
A promoção de vivências em que os alunos, no processo de entendimento do ambiente, são agentes ativos no cuidado com o meio, com atenção aos problemas ambientais, abre caminhos para o reconhecimento da necessidade de um posicionamento crítico sobre o seu estilo de vida, formas de consumo e de utilização dos recursos naturais, a fim de se perceberem cidadãos e cidadãs responsáveis em buscar alternativas para 0 desenvolvimento de uma cultura inspirada na sustentabilidade.

Sendo assim, a construção deste trabalho foi norteada pela hipótese de que o ensino por meio de atividades interdisciplinares a luz da EA Crítica possibilita a aprendizagem significativa e a consciência de ser e estar no mundo. Para testarmos esta hipótese, propusemos a alunos do Ensino Médio uma série de atividades com enfoque interdisciplinar alicerçadas pela perspectiva Crítica da EA.

\section{O meio ambiente sob a perspectiva interdisciplinar da Educação Ambiental}

Para que algo seja compreendido se faz necessário, prioritariamente, que ele seja conhecido. A percepção do ambiente envolve a compreensão de um espaço onde se articulam natureza, técnica e cultura através da gestão coletiva de atores sociais (JACOBI, 2003). O conceito de meio ambiente subjuga a determinação de um mero objeto específico, mas retrata uma relação de interdependência entre o humano $X$ humano e humano $X$ natureza (KRZYSCZAK, 2016).

Os heterogêneos atores sociais percebem o ambiente de maneiras diversas e a definição atribuída ao ambiente está diretamente relacionada com a maneira que 0 sujeito percebe a realidade que 0 rodeia. Perceber 0 ambiente, entre outras coisas, está relacionado a ter consciência sobre ele, seja inserindo-se, aprendendo, protegendo ou cuidando. Ou seja, a percepção do meio está ligada à forma como estamos conectados ou não a ele (OLIVEIRA, 2003; KRZYSCZAK, 2016).

Neste sentido, é importante ter em vista as inter-relações existentes nas diversas dimensões ambientais bem como desenvolver metodologias integradoras que contemplem toda a complexidade dos processos socioambientais de maneira a relacionar os conhecimentos, outrora embarreirados por disciplinas ou áreas de conhecimento, na perspectiva de ressignificação da atuação, individual e coletiva, no mundo (LOUREIRO, 2012).

Para atender à necessidade de superação das barreiras do conhecimento, a interdisciplinaridade se revela uma ferramenta de integração bastante útil frente ao entendimento da complexidade dos processos biossociais. Porém, não como instrumento de mera unificação de conhecimentos ou como colaboração de especialistas de diferentes áreas, mas como uma "hibridação entre ciências, técnicas e saberes" (LEFF, 2002, p. 175).

Esta ferramenta se concretiza com a construção de uma realidade 
multifacetada, multidimensional, porém, homogênea, sobre a qual se projetam diferentes enfoques disciplinares.

Uma analogia bastante útil e didática para explicar a interdisciplinaridade é a de fios soltos tramados num tecido: "Ao puxar apenas um fio, tratando-o como fato único e isolado, cada área especializada do conhecimento, não apenas perde a visão do conjunto como pode esgaçar irremediavelmente essa trama onde tudo está entrelaçado" (CARVALHO, 1998, p. 27). Ou seja, a multidimensionalidade do objeto de estudo - as relações com ambiente, especificamente - sem a luz da interdisciplinaridade ficam limitadas ao olhar solitário, individual e fragmentado das disciplinas isoladas.

O eixo construtivo dos currículos deve estar sustentado na interdisciplinaridade e na contextualização para que haja engajamento entre os professores num trabalho conjunto de conectar conhecimentos, ultrapassando o simples ensinar e superando a fragmentação do saber (MIRANDA, MIRANDA e RAVAGLIA, 2017). Lançar reflexões a respeito dos desafios ambientais e da função da educação para os tempos atuais e futuros, diante de uma ótica interdisciplinar é também, convocar todas as disciplinas para formar grupo de docentes competentes e integrados que mediarão o aprendizado para a melhoria das relações humanas e do ser humano com a natureza (FAZENDA; CASADEI, 2012).

\section{Educação Ambiental em todos os espaços de ensino a partir da Ecopedagogia e da Educomunicação}

Segundo as Diretrizes Curriculares Nacionais em Educação Ambiental, regulamentada pela Resolução nํㅡ 2 de 15 de junho de 2012, a EA é obrigatória em todos os níveis da educação básica (BRASIL, 2012) e pode ser realizada em caráter formal e não formal (BRASIL, 1999) podendo ser vivenciada também em ambientes não formais de ensino, que, quando bem direcionados, podem ser aliados dos conteúdos curriculares de Biologia e incentivar o fortalecimento de posturas críticas em avaliar como a sociedade interfere na natureza (BARBOSA et al., 2016).

No contexto integrador da interdisciplinaridade, retomamos novamente

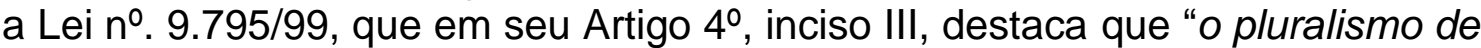
ideias $e$ as concepções pedagógicas, na perspectiva inter, multi e transdisciplinar" devem ser observados como princípios básicos da Educação Ambiental (BRASIL, 1999). A proposta essencialmente interdisciplinar da EA implica profundas mudanças nos modos de ensinar e aprender, bem como na organização formal das instituições educacionais, desde a construção e o estabelecimento de novas metodologias, reestruturação de currículos até a aclimatação de profissionais (CARVALHO, 1998), enfim, exige mobilização de toda a organização escolar e dos espaços educacionais. Quando desenvolvida com enfoque interdisciplinar em espaços formais, não formais e informais, numa perspectiva de interpretação da realidade, a EA atende às demandas das 
relações socioambientais estabelecidas no mundo atual (GOHN, 2006).

De acordo com a teoria da assimilação da aprendizagem e da retenção significativa de Ausubel, o indivíduo aprende significativamente quando a nova informação é incorporada à sua estrutura cognitiva, fazendo conexões com os conhecimentos prévios do aprendiz, oportunizando não só o aprendizado, mas também a transferência do que foi aprendido para ser utilizado em um contexto diferente do que o materializou (TAVARES, 2008). Nesse sentido, duas condições são prioritárias: em primeiro lugar, a disposição do aluno para aprender e, em segundo lugar, o potencial de significância do conteúdo escolar a ser aprendido (PELIZZARI et al., 2002).

A ecopedagogia, inicialmente chamada de pedagogia para 0 desenvolvimento sustentável, hoje, um movimento político e social que se preocupa não apenas com relações saudáveis, mas com aquilo que fazemos de nossa existência a partir das nossas ações no cotidiano, compromete-se em orientar as relações humanas, sociais e ambientais atuais e transformá-las (GADOTTI, 2013). Esta pedagogia é orientada pelos fundamentos pedagógicos freireanos e, assim, está voltada para as relações entre os sujeitos que aprendem juntos, a partir de uma educação que se preocupa com o sentido da aprendizagem e o problematiza, atribuindo, assim, sentido social ao ensino (CARVALHO, 2018).

A educomunicação também reflete ideais da pedagogia freiriana, pois, anuncia a importância do estabelecimento de inter-relações entre a comunicação (essencial para o processo educativo) e a educação, criando um campo de diálogo que promove intercâmbio social, conhecimento e comportamento como autoexpressão de uma cidadania comunicativa (LÓPEZ, 2018). A educomunicação oportuniza não só a veiculação de informações, mas também a criação de conteúdo próprio da vivência, estimulando, assim, a mobilização e mudanças na realidade local, valoriza os contextos históricos, culturais e sociais e supera práticas educativas insuficientes para os dias atuais (CORTES, MARTINS e SOUZA, 2018).

\section{Sustentabilidade por meio da Educação Ambiental Crítica}

Segundo o Relatório de Brundtland, o desenvolvimento sustentável pode ser entendido como a forma como as atuais gerações satisfazem as suas necessidades não comprometendo as capacidades de satisfação das necessidades de gerações futuras (BRUNDTALND, 2020). Esta satisfação de necessidades, no passado, era vista sob a ótica da do desenvolvimento sustentável hegemônico, conservador e fragmentado, pautado no interesse econômico (TEIXEIRA; AGUDO; TOZONI-REIS, 2017).

Hoje, as necessidades humanas são compreendidas também na esfera do bem-estar social, da redução das desigualdades, da participação cidadã, do acesso universal aos recursos e serviços básicos e da economia solidária (LÓPEZ, 2018); dessa forma, explicita-se a necessidade de entender 
sustentabilidade no sentido de harmonizar direitos humanos fundamentais que só podem ser alcançados concomitantemente, pois separados se contrapõem (VILCHES; PÉREZ, 2016).

Neste sentido, enquanto proposta de educação política transformadora, a EA deve distanciar-se da ecologia biológica no sentido de relacionar-se apenas em preservar e conservar os ecossistemas. Para tanto, necessita comprometer-se com a ampliação da cidadania na procura de alternativas que permitam a coexistência digna voltada para o bem-estar das comunidades (REIGOTA, 2001).

Em oposição ao modelo educacional opressor, em que o educando é mero receptor e memorizador de informações, a educação problematizadora surge como estratégia capaz de fomentar curiosidades e desafios, a fim de superar a passividade dos educandos e mobilizá-los à conscientização através da prática dialógica (FREIRE, 1987).

A EA Crítica, que abraça os princípios freireanos, possui caráter emancipador, prevê reflexões profundas na interpretação do sentido da existência humana e o seu papel como ser integrante da natureza, bem como, a libertação de concepções ultrapassadas com vistas à visualização das possibilidades de construção de caminhos que a coletividade julgar mais adequados à vida em sociedade vinculados às esferas social, cultural, política, histórica e econômica (LOUREIRO, 2012).

Consoante a esse pensamento, 0 desafio da EA perpassa 0 desenvolver uma educação que supere o "a respeito do, para o ou em prol do" meio ambiente, e, sobretudo, objetive a nossa relação saudável com 0 ambiente (SAUVÉ, 2005). No entanto, não como responsável por resolver as causas de toda problemática biossocial, mas como mecanismo fundamental na construção aprimorada de novos modelos de organização social que superem os antigos ou atuais, ineficientes (RODRIGUES; GUIMARÃES, 2010).

\section{Metodologia}

A pesquisa foi realizada no Município de Araripina, cidade pertencente à Zona Fisiográfica do Sertão do Araripe, plantada na Chapada do Araripe a $623 \mathrm{~km}$ da Capital Pernambucana. Está localizada na tríplice divisa entre Pernambuco - Piauí - Ceará, tem uma população de 77.302 habitantes (dados do censo 2010), no entanto, estimativa mais recente, de 2019, denota uma população de 84.418 habitantes; possui clima semiárido quente e vegetação característica ao bioma Caatinga (BRASIL, 2019 a).

Esta pesquisa foi desenvolvida em uma das escolas públicas estaduais do Município de Araripina - PE, escola de referência em ensino médio de tempo integral que atende alunos de 14 a 18 anos de idade. Esta escola atende um percentual significativo de estudantes residentes nos distritos municipais, sítios e povoados, áreas caracterizadas como rurais ou "menos 
urbanas" - mais naturalizadas, como sugere Guimarães (2005), pela sua distância do centro urbano principal, por sua organização estrutural e econômica e pela presença, em maior proporção, de elementos da natureza não modificados. Do total de alunos que participaram do estudo, 54,5\% residiam em distritos municipais, sítios ou povoados e $45,5 \%$ no distrito sede do município de Araripina ou de outras cidades próximas.

A amostra para esse trabalho foi de 33 alunos, com idade entre 15 (quinze) e 17 (dezessete) anos. Foi formada uma turma com alunos representantes de todas as turmas da $1^{\underline{a}}$ série $(A, B, C, D, E$ e $F)$ e da $2^{\underline{a}}$ série (A, B, C, e D), aproximadamente 4 (quatro) alunos de cada turma se inscreveram para cursar a disciplina eletiva "Vivendo em harmonia com o ambiente", vivenciada durante os meses de agosto a dezembro do ano letivo de 2019 e em fevereiro do ano letivo de 2020.

\section{Caminhos metodológicos}

O presente estudo seguiu os caminhos metodológicos da PesquisaAção com abordagem quanti-qualitativa. Entrevistas semiestruturas foram utilizadas como instrumento de pesquisa, executadas antes e depois da realização das atividades interdisciplinares.

As entrevistas foram realizadas individualmente, em local reservado, os áudios dos depoimentos foram gravados em mídia digital e, em seguida, transcritos na íntegra. Os (as) estudantes foram identificados (as) por letras do alfabeto de acordo com a ordem de citação das mesmas, do mesmo modo, os depoimentos fornecidos na segunda entrevista foram identificados pelas letras do alfabeto, no entanto, com a adição de um sinal apóstrofo (').

\section{Vivenciando a interdisciplinaridade}

Paulo Freire (1987), propõe um método de ensino que parte, prioritariamente, do respeito aos saberes dos educandos construídos na prática comunitária e afirma a necessidade de integração desses saberes com os curriculares fundamentais.

Nessa perspectiva, esta etapa estreou com o levantamento de temas geradores inerentes aos alunos, por meio do preenchimento individual da Tabela de Saberes (TS) (BRASIL, 2019 a). A TS é uma tabela dotada de campos específicos para elencar assuntos de interesse e relacioná-los a uma importância, um grau de significância para a vida, com o que os alunos já conhecem e o que esperam conhecer sobre determinado tema. Após este momento, as atividades foram direcionadas e orientadas para a formulação e o desenvolvimento de atividades interdisciplinares voltadas para práticas ecopedagógicas e oficinas de educomunicação de acordo com as áreas de interesse manifestadas por eles na TS. 


\section{Práticas Ecopedagógicas e Oficinas Educomunicativas}

A partir do universo temático revelado nos assuntos elencados na TS, foram realizadas atividades dinâmicas que oportunizaram o entendimento dos alunos da inter-relação do cotidiano de cada um com o ambiente. Todas as práticas ecopedagógicas foram apresentadas a partir de uma questão problematizadora inicial seguida de reflexão e levantamento de hipóteses para sua resolução. Nas oficinas foram produzidos materiais informativos/educativos por meio da utilização de vários tipos de linguagens, abordagens e recursos.

\section{Avaliação do Percurso}

Esta etapa foi reservada para o momento de socialização e multiplicação do conhecimento construído durante as etapas anteriores. Os alunos foram organizados em grupos de acordo com as temáticas vivenciadas nas práticas ecopedagógica e estimulados a expor para a comunidade escolar os materiais produzidos nas oficinas educomunicativas. Ao final, a segunda Entrevista Semiestruturada foi realizada, com a finalidade de avaliar a efetividade das ações interdisciplinares executadas.

\section{Resultados e discussão}

\section{Interdisciplinaridade}

Neste estudo, a interdisciplinaridade buscou unificar a realidade multifacetada, evidenciada pelos temas geradores, na perspectiva de que, unificadas, confluíssem para a ressignificação do sentido da existência e das identidades individuais e coletivas dos alunos.

As temáticas principais apresentadas pelos alunos na TS foram aquelas relacionadas à área das Ciências da Natureza e suas Tecnologias, às Ciências Humanas e Sociais Aplicadas e às Linguagens e suas Tecnologias. Além das disciplinas e temas correlatos, eles também descreveram o que desejavam aprender sobre cada assunto (ver exemplo em SILVA et al., 2020). Essas expectativas direcionaram as práticas ecopedagógicas e as oficinas educomunicativas.

Os temas geradores levantados pelos alunos envolvendo as Ciências da Natureza foram: a) Preservação dos recursos naturais - preservar, reciclar, manter o ambiente limpo e equilibrado, plantar; b) Prevenção de doenças prevenir doenças virais e bacterianas disseminadas na escola; c) Saúde corporal e mental - aprender a cuidar-se, prevenir o suicídio, lidar com conflitos internos.

A preservação dos recursos naturais foi experenciada por meio das sequências ecopedagógicas "Meu lixo, eu me lixo" e "Trilhas interpretativas". A prevenção de doenças foi vivenciada juntamente com a disciplina de Química, por meio da execução da prática ecopedagógica "Fortalecendo hábitos 
sustentáveis" (SILVA et al., 2020). A saúde corporal e mental abordou especificamente a prevenção e o combate ao suicídio e o autocuidado por meio da prática "Sua vida importa".

A abordagem de assuntos inerentes ao meio ambiente, sob o perfil disciplinar das Ciências Humanas e Sociais ficou a cargo das temáticas sobre a vida em sociedade e a diversidade cultural. As expectativas de aprendizagem lançadas sobre elas estavam voltadas para a apropriação dos direitos humanos, o posicionamento crítico frente às demandas sociais e a valorização das diversas manifestações culturais. Essas temáticas foram vivenciadas em parceria com o Núcleo de Estudo de Gênero de Araripina - NEGARI, que atua na escola e que tem por finalidade a promoção de ações de valorização da mulher, igualdade entre os sexos e luta contra o preconceito. As sequências didáticas ecopedagógicas desenvolvidas para alcançar tais expectativas foram as seguintes: "Isso é violência?" e "Somos todos da raça humana" (SILVA et al., 2020). Em todas as etapas, por meio da construção de materiais educomunicativos, as Linguagens e suas tecnologias tornaram-se essenciais e, ao mesmo tempo, indissociáveis de qualquer proposta ecopedagógica deste estudo, pois elas permearam todas as práticas e oficinas desenvolvidas.

A aplicabilidade da ecopedagogia e da educomunicação, partindo dos interesses do estudante, contribuiu para formar a autonomia, o senso crítico e reduzir a distância entre o que é ensinado e o contexto cultural no qual os alunos estão inseridos, ou seja, a formação de uma consciência cidadã necessária para os dias atuais (CECCON, 2012). Nesse sentido, nos aproximamos da proposta de uma educação problematizadora como estratégia capaz de fomentar curiosidades e desafios, a fim de superar a passividade dos educandos e mobilizá-los à conscientização através da prática dialógica (FREIRE, 1987). A proposta dialógica se opõe ao método bancário de ensino e contempla a relação entre ação-reflexão-ação transformadoras fomentada pelos temas geradores como princípio de valorização de experiências pessoais e aprendizado (JARDIM; MENDONÇA, 2017).

Os temas geradores sugeridos pelos alunos foram temas que realmente os tocam em sua existência. Porém, de onde emergiram esses temas? As demandas locais são advindas da comunicação global, da diversa gama de bens e serviços que geram acúmulo de problemas os quais refletem nas realidades locais (OLIVEIRA, 2010). Os jovens são fortemente atingidos pelas transformações sociais e a partir delas apresentam formas distintas de atuar no mundo. Em vista disso, levamos em consideração que os temas levantados pelos estudantes como geradores de discussões reflitam um nível elementar de consciência diante do seu papel na sociedade socialmente justa e ecologicamente equilibrada (TOZONI-REIS, 2006). Nesse sentido, acreditamos que os estudantes apresentam mesmo que ingenuamente, sem consciência crítica de ser possuidor do saber, compreensão sobre os aspectos políticos, históricos e sociais inerentes à sua existência e são detentores de capacidade crítica. As temáticas levantadas denotam as esperanças, as aspirações dos alunos, refletem as formas como estão inseridos na sociedade e ratificam o 
desejo de (re) construir uma sociedade em que se reconheça a justiça e a solidariedade.

Cada sequência didática desenvolvida, culminou na produção de um produto educomunicativo. A sequência "Meu lixo, eu me lixo" contribuiu para a confecção de lixeiras utilizadas no ambiente escolar; a "Trilhas interpretativas" encerrou com uma exposição de imagens e vídeos produzidos no percurso da trilha; a "Fortalecendo hábitos saudáveis" produziu sabão líquido artesanal para ser utilizado na escola; a "Sua vida importa!" confeccionou um mural interativo; as "Somos todos da raça humana" e "Isso é violência" confluíram para a produção de apresentações teatrais, interpretação de poemas, músicas e exposição fotográfica (Quadro 1).

Quadro1: Elenco de sequências ecopedagógicas e seus produtos educomunicativos.

\begin{tabular}{|c|c|c|}
\hline Área do Conhecimento & $\begin{array}{c}\text { Sequência } \\
\text { ecopedagógica }\end{array}$ & Produto educomunicativo \\
\hline \multirow{3}{*}{ Ciências da Natureza } & Meu lixo, eu me lixo & $\begin{array}{c}\text { Produção de lixeiras a partir de } \\
\text { materiais reutilizáveis. }\end{array}$ \\
\hline & Trilhas interpretativas & $\begin{array}{c}\text { Exposição de registros fotográficos e } \\
\text { de vídeo produzidos durante o } \\
\text { percurso da trilha. }\end{array}$ \\
\hline & $\begin{array}{l}\text { Fortalecendo hábitos } \\
\text { sustentáveis }\end{array}$ & $\begin{array}{c}\text { Produção de textos informativos; } \\
\text { Produção de sabão líquido para uso } \\
\text { nos banheiros da escola. }\end{array}$ \\
\hline \multirow{3}{*}{ Ciências Humanas e Sociais } & Sua vida importa! & Mural interativo. \\
\hline & $\begin{array}{c}\text { Somos todos da raça } \\
\text { humana }\end{array}$ & $\begin{array}{c}\text { Exposição de galeria fotográfica da } \\
\text { beleza de alunos negros; } \\
\text { Interpretação de músicas. }\end{array}$ \\
\hline & Isso é violência? & $\begin{array}{l}\text { Escrita, produção e encenação de } \\
\text { peça teatro falado e do tipo } \\
\text { pantomima (apenas com expressão } \\
\text { corporal). }\end{array}$ \\
\hline
\end{tabular}

Fonte: Compilação dos autores.

As práticas realizadas proporcionaram momentos de reflexão sobre o posicionamento de cada aluno frente às situações propostas, e ofereceram oportunidades de intervenção sobre elas. A abordagem de situações dentro do universo temático, no qual estão inseridos, concede mecanismos de enxergar meios de melhor atuar sobre a realidade socioambiental e transformá-la (TORRES; LOUREIRO, 2014). Nesse contexto, a prática educativo-crítica que põe o processo educacional em favor do desenvolvimento da autonomia do ser, não rejeita a história e a cultura do indivíduo e procura "depositar" novos conhecimentos desconexos de sua realidade comunitária. Pelo contrário, respeita seus saberes construídos durante a vida e busca meios de oferecer aos sujeitos condições de, diante da sua forma de ver, interpretar e agir no 
mundo, protestar contra injustiças, de atuar como sujeito da história, superando o determinismo e a acomodação com a realidade (FREIRE, 1996).

A vivência da EA a partir dos temas geradores facilitam o processo educativo, pois os temas geradores se forjam nas expressões das demandas inerentes ao grupo social com o qual se trabalha. No entanto, é importante estarmos atentos à necessidade da superação do pragmatismo nas ações desencadeadas, para que, por meio de um processo coletivo de escolhas de temas as ações não tenham efeitos apenas pontuais, inconscientes. A proposta da EA à luz da criticidade é exatamente a libertação da inconsciência, do fazer por fazer, da mecanização das ações dos sujeitos sociais, está pautada na aproximação crítica com a realidade (LOUREIRO, 2012).

De maneira alguma acreditamos que conseguimos resolver os conflitos pessoais e coletivos expressos pelos estudantes durante a realização das atividades interdisciplinares ecopedagógicas, seria ingênuo pensar assim. Contudo, acreditamos que esses momentos pedagógicos se concretizam em grandes oportunidades de crescimento, para os estudantes e para a professora participante que atuou como mediadora, incluída, diretamente, no processo de construção do aprendizado.

As propostas didáticas apresentadas aos alunos criaram uma atmosfera reflexiva que ultrapassou os limites das paredes das salas de aulas e espalhou-se pelo pátio da escola num projeto de disseminação do agir coordenado com a vida em harmonia com o ambiente e, por meio da Tabela dos Saberes, os estudantes sinalizaram temas que geraram discussões acerca do relacionamento do humano com a natureza, da vida em sociedade, da necessidade de conhecimentos para prevenir-se de doenças, e do uso de diferentes tipos de linguagens nas comunicações, especialmente na escolar.

\section{Avaliação do Percurso}

Neste item será apresentado a análise comparativa da entrevista I (E1), anterior à realização das práticas ecopedagógicas e produção de materiais educomunicativo, e da entrevista 2 (E2), posterior a elas.

O entendimento acerca do foco interdisciplinar da EA encontrado nessa pesquisa se assemelha aos achados de Jaeger e Freitas (2021) quando abordaram esta mesma temática com professores de escolas públicas do Rio Grande do Sul. Foi observado que quando se trata de atribuir a responsabilidade da EA a "alguém" a maioria se volta para as Ciências da Natureza. As disciplinas mencionadas na E1 foram prioritariamente Biologia citada por 93\% dos alunos, seguida da Química e Geografia (Quadro 2). Os estudantes mostraram entender que a EA é um tema a ser vivenciado no âmbito da disciplina de Biologia e enfatizaram esse entendimento com as frases: "biologia é claro", "biologia, lógico" e "com certeza Biologia". O adjetivo que qualifica este tipo de educação como ambiental remete a ideia de ambiente 
como natureza, logo os estudantes associam a responsabilidade dessa educação às Ciências da Natureza, especificamente à Biologia.

Em contrapartida, na E2 $88 \%$ dos alunos assinalaram que a EA é responsabilidade de todas as disciplinas. Eles demonstraram compreensão da possibilidade, bem como da importância da vivência da EA de modo a estabelecer integração entre as áreas do conhecimento dos processos biossociais com a finalidade de vislumbrar a realidade com suas múltiplas facetas, sobre enfoques disciplinares distintos (LEEF, 2002). A vivência de assuntos socioambientais sob a perspectiva interdisciplinar ajuda a despertar nos estudantes a necessidade de tratar das questões ambientais em todas as disciplinas, diante da possibilidade de superar o ensino formal (CASAGRANDE; FRANÇA; FORTUNA, 2019).

As unidades de análises obtidas a partir da E1 revelam uma visão inicial reducionista, que enxerga o ambiente como natureza contemplativa ou degradada e como lugar de habitação e que define como problema ambiental aqueles relacionados à degradação da natureza, poluição, desmatamento e queimadas. $\mathrm{Na}$ E2, as concepções de ambiente mostraram-se ampliadas para um conjunto de relações sociais estabelecidas num determinado ambiente físico, afetando-o e sendo afetadas por ele. Quanto aos problemas ambientais, à lista anteriormente mencionada foram acrescidos problemas de cunho socioambiental como preconceito, depressão, desigualdades sociais e doenças (Quadro 2).

Quadro 2: Respostas mais frequentes dos estudantes nas duas entrevistas. $\mathrm{E} 1=$ primeira entrevista; E2 = segunda entrevista.

\begin{tabular}{|c|c|c|}
\hline Perguntas & Respostas E1 & Respostas E2 \\
\hline $\begin{array}{l}\text { 1. Em quais disciplinas } \\
\text { podemos trabalhar } \\
\text { assuntos relacionados } \\
\text { ao Meio Ambiente? }\end{array}$ & $\begin{array}{l}\text { Biologia; } \\
\text { Química; } \\
\text { Geografia. }\end{array}$ & Todas. \\
\hline $\begin{array}{l}\text { 2. Para você, o que é Meio } \\
\text { Ambiente? }\end{array}$ & $\begin{array}{l}\text { Elementos da natureza; } \\
\text { Lugar em que se vive. }\end{array}$ & $\begin{array}{c}\text { Conjunto de relações estabelecidas } \\
\text { num determinado espaço físico, } \\
\text { influenciando-o e sendo } \\
\text { influenciadas por ele. }\end{array}$ \\
\hline $\begin{array}{l}\text { 3. Cite três problemas } \\
\text { ambientais que você já } \\
\text { ouviu falar ou vivenciou. }\end{array}$ & $\begin{array}{c}\text { Poluição; } \\
\text { Queimada; } \\
\text { Desmatamento; }\end{array}$ & $\begin{array}{l}\text { Poluição como consequência da } \\
\text { inexistência de coleta de lixo; } \\
\text { Desigualdades sociais; } \\
\text { Violência doméstica; } \\
\text { Preconceito; }\end{array}$ \\
\hline $\begin{array}{l}\text { 4. Na sua cidade, bairro ou } \\
\text { escola existe algum } \\
\text { problema ambiental que } \\
\text { você consegue } \\
\text { identificar? Quais? }\end{array}$ & $\begin{array}{c}\text { Sim. } \\
\text { Descarte inadequado } \\
\text { de lixo; } \\
\text { Ausência de } \\
\text { saneamento básico; }\end{array}$ & $\begin{array}{c}\text { Sim. } \\
\text { Deficiência da rede de esgoto } \\
\text { municipal; } \\
\text { Presença de mosquitos; } \\
\text { Fábricas poluidoras; Desmatamento; } \\
\text { Bullying; } \\
\text { Depressão/Automutilação; } \\
\text { Doenças; }\end{array}$ \\
\hline
\end{tabular}

Fonte: Compilação dos autores.

Revbea, São Paulo, V. 16, № 4: 340-358, 2021. 
Na E1 $79 \%$ deles demonstraram entender o ambiente por meio de elementos prioritariamente do reino vegetal - fragmentados ("planta" e "árvore") ou associados ("florestas", "lugares verdes") - podendo estar acompanhado de outros elementos naturais não vegetais como as bacias hidrográficas ("rios", "cachoeiras"). Essa visão naturalista pode ser sintetizada na seguinte frase, que se repetiu algumas vezes durante a entrevista: "Ambiente é tudo que tem a ver com a natureza" (estudante $A$ '). Já na E2, os alunos, que haviam julgado meio ambiente enquanto natureza, passaram a defini-lo como um lugar físico em que há relações entre os seres e que essas têm efeitos sobre eles: "É $O$ lugar que as coisas, vivas ou não, se relacionam, bem ou mal" (estudante B'). "São coisas naturais e não naturais. A natureza, as pessoas, os animais $e$ outros seres e como eles se envolvem num lugar" (estudante C'). "Todos os lugares do mundo onde a gente vive com outros seres e as formas como a gente interage" (estudante D'). "Conjunto de interações sociais num determinado espaço" (estudante E').

Estas novas concepções se distanciam da inicial, meramente naturalista, que representa o ambiente apenas por seus elementos naturais e da antropocêntrica, que concebe o todo sob a ótica da necessidade humana (REIGOTA, 2001). As novas concepções se aproximam de uma concepção globalizante, em que o meio ambiente é integrado entre natureza e sociedade, sob a perspectiva de superação da compartimentalização dos espaços em busca da conscientização da coletividade e suas implicações (REIGOTA, 2007).

Em relação às ideias iniciais de problemas ambientais esboçadas na $E 1$, os alunos demonstraram perceber a poluição, queimadas e 0 desmatamento como problemas ambientais. Já que inicialmente o ambiente representava natureza, é natural relacionar os problemas ambientais apenas à degradação do ambiente natural. Estes são problemas ecológicos graves, muito divulgados em toda mídia, muito disseminados pelos livros didáticos e por professores.

Acreditamos que isto se deve ao fato da influência da mídia e dos livros didáticos, uma vez que os problemas citados são comumente noticiados pelos veículos de comunicação (TV, Sites, Redes Sociais) e abordados nas salas de aulas, principalmente pelas disciplinas de Biologia e Geografia (CASTOLDI; BERNARDI; POLINARKI, 2009). Há também uma tendência de negar a sua responsabilidade sobre os conflitos ambientais e denunciar problemas de autoria do "outro" eximindo-se da responsabilidade e da possibilidade de atuação para a resolução do problema (CASAGRANDE; FRANÇA; FORTUNA, 2019).

A partir das respostas na E2, podemos visualizar que a percepção se tornou biossocial, pois sinalizou não só problemas que estão diretamente relacionados com a natureza em decorrência da ação antrópica, mas os que também tem a ver com a vida humana em sociedade, pautada nos diversos estilos de organizações. Foram descritos problemas como as consequências 
da ausência de coleta de lixo em seus bairros, desigualdades sociais, violência doméstica e preconceito étnico.

Ainda na E1, quando indagados sobre problemas ambientais na sua cidade, no seu bairro e/ou na escola, eles elencaram a poluição atmosférica e aquática, o descarte inadequado do lixo doméstico e a ausência de saneamento básico como principais problemas enfrentados na cidade e/ou nos bairros onde vivem. $58 \%$ reconheceram a presença de lixo nas salas de aulas, nos arredores da quadra poliesportiva e a ausência de árvores como problemas ambientais, enquanto $42 \%$ dos alunos afirmaram não enxergar problemas ambientais na escola. Esse percentual tão expressivo é compatível com a visão ambiental inicial, naturalista, afinal, se o indivíduo não se reconhece integrado ao ambiente, como reconhecerá conflitos inerentes a ele? Não se reconhecer no mundo põe o humano numa posição alheia a ele, desinteressado do que acontece nele. Paulo Freire (1996) ao se contrapor ao condicionamento do ser e fomentar a participação ativa, responsável e ética, de homens e mulheres nos contextos sociais, históricos e políticos, nos oferece uma ilustração de como a presença humana deve ser: "...não é a de quem a ele se adapta, mas a de quem nele se insere. É a posição de quem luta para não ser apenas objeto, mas o sujeito também da história" (FREIRE, 1996, p. 53).

$\mathrm{Na}$ E2, no instante do último questionamento, os alunos conseguiram relacionar a presença de mosquitos à deficiência da rede de esgotos do município; que a indústria gesseira e outros setores econômicos causam adoecimento na população e danos ecológicos graves, além de atribuir a outras demandas como o bullying, depressão, automutilação o status de problema ambiental, segundo eles, estes três últimos são problemas muito comuns no ambiente escolar.

Este novo posicionamento crítico, concorda com a perspectiva de educação emancipatória proposta por Paulo Freire e que fundamenta a EA por meio da abordagem crítica, que prevê reflexões profundas na interpretação do sentido da existência humana e o seu papel como ser integrante da natureza, bem como a libertação de concepções ultrapassadas, com vistas à visualização das possibilidades de construção de caminhos que a coletividade julgar mais adequados à vida em sociedade, vinculados às esferas social, cultural, política, histórica e econômica (LOUREIRO, 2012).

Consideramos que há um longo caminho a ser percorrido para a que a EA seja plenamente vivenciada nos âmbitos da formação básica, em especial no Ensino Médio, contudo, é urgente a necessidade de fomentar a formação profissional continuada dos professores voltada para a complexidade das dinâmicas sociais, sintonizada com os desafios postulados na Agenda 2030 (BRASIL, 2019 b).

Reforçamos a importância da EA presente em todas as modalidades de ensino, permanente e interdisciplinarmente, como via de responsabilização pessoal, social e planetária que leva em consideração os diversos ambientes

revista brasileira educação ambiental 
ocupados por diferentes grupos sociais, sua história e sua cultura e que por meio dela só se pode intervir e transformar a realidade reconhecendo e agindo nas diferentes dimensões ambientais e, sobretudo, enxergando a educação como meio sem a qual não há mudança.

\section{Conclusões}

O presente estudo partiu da hipótese de que o ensino por meio de atividades interdisciplinares a luz da EA crítica possibilita a aprendizagem significativa e a consciência de ser e estar no mundo. Para testarmos esta hipótese, propusemos a alunos do Ensino Médio uma série de atividades com enfoque interdisciplinar alicerçadas pela perspectiva Crítica da EA. Acreditamos que os resultados aqui alcançados nos dão suporte para aceitar esta hipótese. A Educação Ambiental crítica sob enfoque interdisciplinar oferece caminhos para interconexão de conhecimentos, novos e antigos, rumo à superação da fragmentação do saber e da educação baseada no depósito de informações, com vistas à educação emancipatória.

Constatamos, a partir dos métodos utilizados, que os estudantes, predominantemente, assumiam uma visão de meio ambiente meramente naturalista, quase que exclusivamente caracterizado por plantas. Porém, por meio da sensibilização durante as práticas desenvolvidas, as novas concepções não ignoraram o naturalismo, mas a ele acrescentou a presença humana e de outros seres integrados através de uma rede de interrelações capaz de determinar o lugar físico que eles ocupam e este interferir na vida dos seres.

A execução dessa ação metodológica não se comprometeu em desvincular os elementos da natureza da caracterização de ambiente, mas sim em oferecer subsídios de ampliação da visão limitada, apenas naturalista, em busca da construção de uma visão multidimensional e, sobretudo, fomentar reflexões sobre as possibilidades de vivenciar relações socioambientais sustentavelmente.

Consideramos que é necessário também que escolas e professores (as) dialoguem nessa perspectiva e pautem os seus Projetos Político Pedagógico (PPP) na perspectiva da vivência da EA perpassando todas as áreas do conhecimento. Especialmente, EA sob a perspectiva crítica, que é a que oferece subsídios de reflexão e busca de caminhos de transformação efetiva da realidade.

A aproximação crítica da realidade, como princípio da Educação Ambiental, não é um resultado imediato da aquisição de conhecimentos sobre os processos biossociais, mas a reflexão cultural e política, repleta de escolhas históricas que resultam na busca de uma sociedade sustentável, verdadeiramente equilibrada. 
Consideramos ainda que foi um privilégio poder ter feito tantas leituras, crescido em conhecimento e ter ampliado nossa própria visão ambiental diante da vertente crítica da EA. E ainda, ao ter sob nossos olhos reveladas as representações ambientais dos estudantes e identificados os temas que os tocavam, podermos contribuir para que eles e elas consigam também encarar a sua realidade socioambiental como algo que depende, diretamente, da sua atuação cidadã e não como fato predeterminado.

Afirmamos com isto, que a prática da Educação Ambiental emancipatória viabiliza o entendimento da responsabilidade social e política da comunidade escolar em busca da vivência de relações sustentáveis e deve ser desenvolvida em todas as etapas do ensino, assim como ser difundida enquanto política educacional em pleno exercício.

\section{Agradecimentos}

À Coordenação de Aperfeiçoamento de Pessoal de Nível Superior (CAPES), pelo apoio financeiro à pesquisa; à Universidade Estadual do Piauí, por tornar possível o mestrado da autora.

\section{Referências}

BRASIL. Parâmetros Curriculares Nacionais. Meio ambiente e saúde. Brasília: MEC/SEF, 1997.

BRASIL. Lei. 9.795, DE 27 DE ABRIL DE 1999. Dispõe sobre a Educação Ambiental, institui a Política Nacional de Educação Ambiental e dá outras providências. Brasil, 1999.

BRASIL. Lei, №. 9394/96. Lei de Diretrizes e Bases da Educação Nacional. Brasil, v. 20, 2010.

BRASIL. Ensino Médio. Resolução no 2, de 15 de junho de 2012, estabelece as Diretrizes Curriculares Nacionais para a Educação Ambiental. Brasília: Diário Oficial da União, 2012.

BRASIL. Ministério do Meio Ambiente. Diretoria de Educação Ambiental. Programa Nacional de Educação Ambiental-PRONEA. Edições MMA. 4ํㅡㄹ ed. Brasília, 2014.

BRASIL. Ministério da Educação. Base Nacional Comum Curricular. Documento homologado pela Portaria oํ 1.570, publicada no D.O.U., Brasília, 2018.

BRASIL. Ministério do Meio Ambiente. Fundamentos e práticas de Educação Ambiental para espaços educadores. Disponível em: $<$ https://ead.mma.gov.br/mod/page/view.php?id=79\&forceview=1>, acesso em: 2019 a. 
BRASIL. Ministério da Educação Conselho Nacional de Educação. 3a VERSÃO DO PARECER, ASSUNTO: Diretrizes Curriculares Nacionais e Base Nacional Comum para a Formação Inicial e Continuada de Professores da Educação Básica. 2019 b.

BARBOSA, T. J. V. B.; PAES, L. S.; MARQUES, J. D. O.; FREITAS, M. S.; TAVARES, L. A. Atividades de Ensino em espaços não formais amazônicos: um relato de experiência integrando conhecimentos botânicos $e$ ambientais. Revista Brasileira de Educação Ambiental, v. 11, n. 4, p. 174183, 2016.

BIASIBETTI, L.; TREVISAN, M. L.; NISHIJIMA, T.; PERES, P. E. C. A concepção dos educadores sobre a temática de Educação Ambiental na escola: dificuldades e desafios. Revista Monografias Ambientais. Santa Maria, v. 14, n. 2, p. 220-237, mai-ago. 2015.

BRUNDTLAND, G. H.; Nosso Futuro Comum. Relatório Brundtland. Our Common Future: United Nations, 1987. Disponível em: http://www.ecobrasil.eco.br/site content/30-categoria-conceitos/1003-nossofuturo-comum-relatorio-brundtland. Acessado em: 07/2020.

CARVALHO, A. M. P. de. Fundamentos teóricos e metodológicos do ensino por investigação. Revista Brasileira de Pesquisa em Educação em Ciências, p. 765-794, 2018.

CARVALHO, I. C. M. Em direção ao mundo da vida: interdisciplinaridade e Educação Ambiental. Brasília: IPÊ - Instituto de Pesquisas Ecológicas, 1998.

CASAGRANDE, J. A.; FRANÇA, L. F.; FORTUNA, J. L. Sensibilizando estudantes do ensino fundamental sobre a conservação das praias utilizando atividades microbiológicas. Brazilian Journal of Development, Curitiba, v. 5, n. 6, p. 7199-7210, jun. 2019.

CASTOLDI, R.; BERNARDI, R.; POLINARSKI, C. A. Percepção dos problemas ambientais por alunos do Ensino Médio. Revista Brasileira de Ciência, Tecnologia e Sociedade, v.1, n.1, p.56-80, 2009.

CAVALCANTE, L. O. H. Currículo e Educação Ambiental: trilhando os caminhos percorridos, entendendo as trilhas a percorrer. In: FERRARO JÚNIOR, L. A. (org). Encontros e caminhos: formação de educadoras (es) ambientais e coletivos educadores. Brasília: MMA, Departamento de Educação Ambiental, v. 1, p. 116-126, 2005.

CECCON, S. Educação Ambiental crítica e a prática de projetos. Produção de terceiros sobre Paulo Freire; Série Livros, 2012.

CORTES, T. P. B. B.; MARTINS, A. de O.; SOUZA, C. H. M. de. Educação midiática, educomunicação e formação docente: parâmetros dos últimos 20 anos de pesquisas nas bases scielo e scopus. Educação em Revista, v. 34, 2018. 
DELORS, J. Educação: um tesouro a descobrir. Relatório para a UNESCO da Comissão Internacional sobre Educação para o século XXI. Setor de Educação da Representação da UNESCO no Brasil; Fundação FaberCastell. Brasília, julho. 2010.

FAZENDA, I. C. A.; CASADEI, S. R. Natureza e Interdisciplinaridade: reflexões para a Educação Básica. Interdisciplinaridade. Revista do Grupo de Estudos e Pesquisa em Interdisciplinaridade, n. 2, p. 43-71, 2012.

FREIRE, P. Pedagogia do Oprimido. $17^{\mathrm{a}}$ ed. Rio de Janeiro: Paz e Terra, 1987.

FREIRE, P. Pedagogia da autonomia: saberes necessários à prática educativa. São Paulo: Paz e Terra, 1996.

GADOTTI, M. Pedagogia da terra. - São Paulo: Peirópolis, 2000. $7^{\text {a }}$ reimpressão, 2013.

GOHN, M. G. Educação não-formal, participação da sociedade civil e estruturas colegiadas nas escolas. Ensaio: avaliação e políticas públicas em educação, v. 14, n. 50, p. 27-38, 2006.

GUIMARÃES, M. A formação de educadores ambientais. Papirus Editora, 2005.

JACOBI, P. Educação Ambiental, cidadania e sustentabilidade. Cadernos de pesquisa, n. 118, p. 189-206, 2003.

JAEGER, A. P.; FREITAS, E. M. Prática de Educação Ambiental: percepção de professores do ensino fundamental de escolas públicas municipais do Rio Grande do Sul. Revista Brasileira De Educação Ambiental, v. 16, n. 1, p. 2334, 2021.

JARDIM, K. F.; MENDONÇA, M. A. X. A. Dialogicidade na educação como prática da liberdade. Universidade Metropolitana de Santos, p. 91, 2017.

KRZYSCZAK, F. R. As diferentes concepções de meio ambiente e suas visões. Revista de Educação do IDEAU, v. 11, n. 23, p. 1-17, 2016.

LEFF, E. Epistemologia ambiental. São Paulo: Cortez, 2002.

LÓPEZ, L. M. R.; LONDOÑO, J. V. E.; RUIZ, A. de J. A.; BENITÉZ, J. A. M.; PARODI, T. V.; MONTAÑA, D. F. V. Educación para el desarrollo sostenible: acercamientos desde una perspectiva colombiana. Producción Más Limpia, v. 13, n. 2, 2018.

LOUREIRO, C. F. B. Trajetória e Fundamentos da Educação Ambiental. $4^{\mathrm{a}}$ ed. São Paulo: Cortez, 2012.

MIRANDA, F. H. F.; MIRANDA, J. A.; RAVAGLIA, R. Abordagem Interdisciplinar em Educação Ambiental. Revista práxis, v. 2, n. 4, 2017.

OLIVEIRA, E. M. Cidadania e Educação Ambiental: uma proposta de educação no processo de gestão ambiental. Ibama, 2003. 
OLIVEIRA, E. M. Cidadania e Educação Ambiental: uma proposta de educação no processo de gestão ambiental. Brasília: Ibama, 2010.

PELIZZARI, A.; KRIEGL, M. de L.; BARON, M. P.; FINCK, N. T. L.; DOROCINSKI, S. I. Teoria da aprendizagem significativa segundo Ausubel. Revista PEC, v. 2, n. 1, p. 37-42, 2002.

PINTO, V. P. dos S.; GUIMARÃES, M. A Educação Ambiental no contexto escolar: temas ambientais locais como temas geradores diante das questões socioambientais controversas. Revista de Geografia-PPGEO-UFJF, v. 7, n. 2, 2017.

REIGOTA, M. O que é Educação Ambiental? Coleção primeiros passos. 2001.

REIGOTA, M. Meio ambiente e representação social. São Paulo: Cortez, 7ª . 2007.

RODRIGUES, J. do N.; GUIMARÃES, M. Educação Ambiental crítica na formação do educador: uma pedagogia transformadora. Anais da 33a Reunião Anual da Associação Nacional de Pós-Graduação e Pesquisa em Educação, Caxambu, 2010.

SAUVÉ, L. Educação Ambiental: possibilidades e limitações. Educação e Pesquisa, São Paulo, v. 31, n. 2, p. 317-332, 2005.

SILVA, P. R. A.; ARAUJO, M. F. V.; FIGUEIREDO, L. S.; KORNDORFER, C. L. A vivência da Educação Ambiental sob a perspectiva crítica mediante abordagens interdisciplinares. 1ed.TERESINA: FUESPI, 2020, v. 1, p. 126142.

TAVARES, R. Aprendizagem significativa e o ensino de ciências. Ciências \& cognição, v. 13, n. 1, 2008.

TEIXEIRA, L. A.; DE MORAES A. M.; TOZONI-REIS, M. $F$ de C. SUSTENTABILIDADE OU "TERRA DE NINGUÉM"?. RTPS-Revista Trabalho, Política e Sociedade, v. 2, n. 2, p. 43-64, 2017.

TORRES, J. R.; LOUREIRO, C. F. B. Educação Ambiental: dialogando com Paulo Freire. São Paulo: Cortez, 2014.

TOZONI-REIS, M. F. C. Temas ambientais como "temas geradores": contribuições para uma metodologia educativa ambiental crítica, transformadora e emancipatória. Educar em revista, n. 27, p. 93-110, 2006.

VILCHES, P. A.; P, D. G. La transición a la Sostenibilidad como objetivo urgente para la superación de la crisis sistémica actual. Revista Eureka sobre Enseñanza y Divulgación de las Ciencias, 2016, vol. 13, num. 2, p. 395-407, 2016. 